Tropical Journal of Pharmaceutical Research December 2020; 19 (12): 2623-2630

ISSN: $1596-5996$ (print); 1596-9827 (electronic)

(C) Pharmacotherapy Group, Faculty of Pharmacy, University of Benin, Benin City, 300001 Nigeria.

Original Research Article

http://dx.doi.org/10.4314/tjpr.v19i12.21

\title{
Evidence-based investigations into the ethnoveterinary use of Mimosa pudica L. (Fabaceae) as an anthlemintic
}

\author{
Terry A Nzeakor ${ }^{1 *}$, Munachimso I Udobi ${ }^{2}$, Ifeanyi G Eke ${ }^{3}$, Ikenna O Ezeh ${ }^{1}$, Idika \\ K Idika1, Ukamaka U Eze ${ }^{4}$, Susan O Dan-Jumbo, Chukwunyere O Nwosu ${ }^{1}$ \\ ${ }^{1}$ Parasitology and Entomology, Faculty of Veterinary Medicine, University of Nigeria, Nsukka, ${ }^{2}$ Department of Veterinary \\ Parasitology and Entomology, College of Veterinary Medicine, Michael Okpara University of Agriculture, Umudike, ${ }^{3}$ Department \\ of Veterinary Physiology and Pharmacology, ${ }^{4}$ Department of Veterinary Medicine, Faculty of Veterinary Medicine, University of \\ Nigeria, Nsukka, Nigeria
}

*For correspondence: Email: terry.ezeudu@unn.edu.ng; Tel: +234-8038043211

Sent for review: 16 January 2020

Revised accepted: 13 November 2020

\begin{abstract}
Purpose: To investigate the toxicity, clinical outcome and anthelmintic effects of M. pudica in vitro and in vivo.

Methods: Dried leaves of M. pudica were extracted using $70 \%$ methanol cold maceration method. Acute toxicity inquiry was evaluated using Lorke's method. Anthelmintic effects were investigated in vitro using the egg hatch assay and in vivo using Heligmosomoides bakeri experimentally infected adult albino mice. Coprological and haematological parameters were recorded during the experiment while the serological analysis and post mortem worm burden were assessed at the conclusion of the research.

Results: No mortality was recorded in oral acute toxicity test up to a dose of $5000 \mathrm{mg} / \mathrm{kg}$. A probit-log analysis of the percentage egg hatch of the extract and albendazole gave lethal concentration 50 ( $\left.L C_{50}\right)$ values of 1.160 and -1.042 , respectively. A reduction in worm count was observed in all the extracttreated groups post mortem, with the maximum extract group having the least worm count $(p<0.05)$. Treatment with extract resulted in improvement in the haematological parameters. Serum chemistry revealed no significant differences $(p>0.05)$ in alanine aminotransferase and blood urea nitrogen in all groups. However, a dose-dependent increases in the total protein and albumin was observed.

Conclusion: These results show that although M. pudica has weak anthelmintic effects compared to albendazole (standard anthelmintic), in vivo and in vitro, at the doses used in this study, nonetheless, it reduces worm burden and improves haematologic parameters, serum total protein, albumin and overall weight gain of the treated mice. Thus, increased doses may be effective in anthelmintic chemotherapy.
\end{abstract}

Keywords: Mimosa pudica, Anthelmintic, Toxicity, Heligmosomoides bakeri, Ethnoveterinary medicine, Anthelmintic

This is an Open Access article that uses a fund-ing model which does not charge readers or their institutions for access and distributed under the terms of the Creative Commons Attribution License (http://creativecommons.org/licenses/by/4.0) and the Budapest Open Access Initiative (http://www.budapestopenaccessinitiative.org/read), which permit unrestricted use, distribution, and reproduction in any medium, provided the original work is properly credited.

Tropical Journal of Pharmaceutical Research is indexed by Science Citation Index (SciSearch), Scopus, International Pharmaceutical Abstract, Chemical Abstracts, Embase, Index Copernicus, EBSCO, African Index Medicus, JournalSeek, Journal Citation Reports/Science Edition, Directory of Open Access Journals (DOAJ), African Journal Online, Bioline International, Open-J-Gate and Pharmacy Abstracts

\section{INTRODUCTION}

Among the various means employed in the control of parasitic infections such as grazing and pasture management, use of vaccines, chemotherapy and biological control chemotherapy remains the most readily available, widely used and effective means of control [1]. This has led to the overburdening of anthelmintics and has precipitated the 
occurrence of resistance in all the classes of anthelmintics worldwide over the years [2].

The rising trend in anthelmintic resistance and high costs of anthelmintics has led rural inhabitants and scientists into the search for other alternatives especially the use of natural plants for the treatment of helminthosis particularly parasitic gastronenteritis (PGE). Parasitic gastroenteritis has resulted in massive economic losses in Nigeria and worldwide [3] and has become a great threat to livestock production. These losses result from the consequent morbidity, mortality, cost of treatment and control.

In many countries including Nigeria, herdsmen and inhabitants of rural areas use various parts of plants (leaves, fruits, stem bark or roots) for the treatment of helminthosis in both animal and man. Mimosa pudica L. is one out of the numerous plants used traditionally for their anthelmintic effects [4]. The plant is an annual/perennial creeping herb belonging to the family Fabaceae. It is commonly known as "touch me not", "sensitive plants" and "shy plant" in English language or "touch and die" among the locals in Nigeria. The plant has been demonstrated to have other medicinal properties such as antidepressant, hypoglycaemic, wound healing, anticonvulsant properties [5]. Mimosa pudica has also been successfully used in the treatment of diarrhea, dysentery and urogenital infections in China, Phillipines, South America and India [6]. The plant was investigated for anthelmintic activities in vitro using larvae of Strongyloides stercoralis [7] and adult Indian earthworm Pheretima posthuma [8].

Although Mimosa pudica L. Has been reported to have various medicinal uses very little in vivo research has been carried out to scientifically validate its anthelmintic effects, safety levels, possible side effects and changes in the blood and serum chemistry picture.

\section{EXPERIMENTAL}

\section{Collection and extraction of plant material}

Fresh leaves of $M$. pudica were gathered from the environs of the University of Nigeria, Nsukka and presented for identification at the Bioresource Development and Conservation Program Centre Nsukka, Nigeria followed by the deposition of a voucher specimen (UNVPP/2014/4722/49) at the herbarium of the Department of Botany, University of Nigeria, Nsukka.
The leaves were air-dried at $25{ }^{\circ} \mathrm{C}$ and pulverized to a fine powder. Extraction was done using the cold maceration method with $70 \%$ methanol as solvent [9]. Filtration of the mixture was done with a Whatman filter paper (No. 1) and the filtrate concentrated at $30^{\circ} \mathrm{C}$ using a hot air oven. The extract (subsequently referred to as methanol leaf extract of M. pudica, MLEMP) was reserved in a refrigerator $\left(4^{\circ} \mathrm{C}\right)$ and the percentage yield $w / w$ calculated using Eq 1.

$X(\%)=(Y / Z) 100$

where $\mathrm{X}=$ yield $(\% w / w), \mathrm{Y}=$ weight of extract $(\mathrm{g})$ and $Z=$ weight of starting material $(g)$.

The extract was subjected to phytochemical analyses according to Trease and Evans [10].

\section{Egg hatch assay}

Egg hatch was done using standard procedures [11] and the inhibition of egg hatch calculated using Eq 2.

$A(\%)=(B-C / B) 100 \ldots \ldots(2)$

where $A=$ inhibition of egg hatching, $B=$ total number of larvae and eggs in a particular well and $\mathrm{C}=$ number of larvae in that well.

\section{Acute toxicity test}

Lorke's method for testing acute toxicity was used [12]. Dose ranges of $10-5000 \mathrm{mg} / \mathrm{kg}$ were assessed using albino rats.

\section{Experimental parasite and animals}

Sixty (60) male albino mice weighing between 28 $-32 g$ were purchased for the experiment. A two weeks period of acclimatization was allowed before the commencement of the study.

\section{Study design}

Thirty (30) of the mice were distributed randomly into 6 groups $(n=5)$ and designated Groups A F. Groups A - E were administered $200 \mathrm{~L}_{3}$ suspended in $0.2 \mathrm{ml}$ of distilled water per os. After the infection established in the mice that were orally administered the parasites, groups $A$ - C served as MLEMP treated groups and received doses of 2,000 $\mathrm{mg} / \mathrm{kg}, 1,000 \mathrm{mg} / \mathrm{kg}$ and $500 \mathrm{mg}$ respectively. Group D remained infected and untreated, group $E$ received $25 \mathrm{mg} / \mathrm{kg} \mathrm{b.wt}$ of a standard anthelmintic (Albendazole) while group $F$ was uninfected and untreated. Mice in groups $D$ and $F$ were given $0.2 \mathrm{~mL}$ of distilled water as the control groups. 
The progress of infection and subsequent disease were monitored through daily clinical examination, faecal egg count (FEC) and changes in haematological parameters. At the conclusion of the experiment (28 days post infection), the mice were humanely sacrificed through euthanasia using Chloroform in an anaesthetic jar. Biochemical parameters and post mortem worm counts were computed afterwards.

\section{Ethical statement}

The stipulations for the use of laboratory animals according to the European Laboratory Animal Science Association and the European Community Council Directive of November 24, 1986 (86/609/EEC) were complied with in this research. The experimental protocol was also approved by the Experimental Animal Ethics Committee of the Faculty of Veterinary Medicine, University of Nigeria, Nsukka (approval no. FVMUNN-IACUC-2018-021) preceding the commencement of the research.

\section{Haematological analysis}

Blood for haematological scrutiny was procured from the retrobulbar plexus in the median canthus of the eye of each mouse. Packed Cell Volume (PCV), Haemoglobin concentration, red and white blood cell counts were determined using standard methods [13,14].

\section{Coprological analysis}

The saturated salt solution floatation method and the McMaster technique were used to obtain the faecal egg counts [11].

\section{Serum biochemistry}

Commercial kits from Randox Laboratories Ltd., UK were used as directed in the manufacturer's user manual, to determine serum total protein, albumin, alanine transaminase and blood urea nitrogen. Serum globulin was deduced from the results of the serum total protein and serum albumin.

\section{Post-mortem worm count}

At the conclusion of the experiment, the experimental mice were euthanized using chloroform in an anaesthetic jar. They were subsequently eviscerated and the intestines obtained. Post mortem worm counts were determined according to the methods of Ngongeh et al [11].

\section{Statistical analysis}

Data generated from the in vitro study (Egg hatch assay) were analysed using Probit log regression analysis, while data from the in vivo study was subjected to statistical analysis using one-way analysis of variance (ANOVA). The results are presented in figures/tables as mean $\pm S D$. The least significant difference test was used to separate variant means. Probability values $\leq$ 0.05 were considered significant (SPSS version 15.0).

\section{RESULTS}

\section{Extraction and phytochemistry}

The extraction yielded $16.39 \% \quad(w / w)$ of a greenish material. Table 1 shows the results of the phytochemical analysis of MLEMP.

Table 1: Phytochemical constituents of MLEMP

\begin{tabular}{lc}
\hline Extract & Present (+) or absent (-) \\
\hline Flavanoids & + \\
Tannins & + \\
Alkaloids & + \\
Starch & - \\
Carbohydrate & + \\
Saponins & + \\
Reducing sugars & + \\
\hline
\end{tabular}

\section{Egg hatch}

A probit analysis of the log-dose response of MLEMP and albendazole on Heligmosomoides bakeri eggs indicated $\mathrm{LC}_{50}$ values of 1.160 and 1.042 (Table 2 and Table 3).

Table 2: Egg hatch at different concentrations of MLEMP

\begin{tabular}{|c|c|c|c|}
\hline $\begin{array}{l}\text { Well } \\
\text { no. }\end{array}$ & 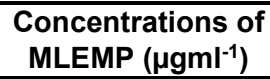 & $\begin{array}{l}\text { Hatch } \\
(\%)\end{array}$ & $\begin{array}{c}\text { Probit } \\
\text { (Hatching) }\end{array}$ \\
\hline 1 & 1000 & 0 & 0 \\
\hline 2 & 500 & 0 & 0 \\
\hline 3 & 250 & 0 & 0 \\
\hline 4 & 125 & 0 & 0 \\
\hline 5 & 62.5 & 0 & 0 \\
\hline 6 & 31.25 & 3.3 & 3.12 \\
\hline 7 & 15.63 & 20 & 4.16 \\
\hline 8 & 7.81 & 23.3 & 4.26 \\
\hline 9 & 3.91 & 26.6 & 4.39 \\
\hline 10 & 1.95 & 33.3 & 4.56 \\
\hline 11 & 0.98 & 36.7 & 4.67 \\
\hline 12 & 0.49 & 36.7 & 4.67 \\
\hline
\end{tabular}


Table 3: Egg hatch at different concentrations of albendazole. Lc50: -1.042

\begin{tabular}{lccc}
\hline $\begin{array}{l}\text { Well } \\
\text { no. }\end{array}$ & $\begin{array}{l}\text { Concentration of } \\
\text { Albendazole } \\
(\boldsymbol{\mu g} / \mathbf{m L})\end{array}$ & $\begin{array}{c}\text { Hatch } \\
(\%)\end{array}$ & $\begin{array}{c}\text { Probit } \\
\text { (Hatching) }\end{array}$ \\
\hline 1 & 50 & 0 & 0 \\
2 & 25 & 0 & 0 \\
3 & 12.5 & 0 & 0 \\
4 & 6.25 & 0 & 0 \\
5 & 3.125 & 0 & 0 \\
6 & 1.5625 & 0 & 0 \\
7 & 0.7813 & 0 & 0 \\
8 & 0.3906 & 0 & 0 \\
9 & 0.1953 & 10 & 3.72 \\
10 & 0.0977 & 16.7 & 4.05 \\
11 & 0.0488 & 20 & 4.16 \\
12 & 0.0244 & 26.7 & 4.39 \\
\hline
\end{tabular}

\section{Acute toxicity}

The mice used for the acute toxicity study did not exhibit any sign of toxicity or death even at the upper limit dose of $5000 \mathrm{mg} / \mathrm{kg}$ per os, consequently, the $\mathrm{LD}_{50}$ of the extract was taken to be above $5000 \mathrm{mg} / \mathrm{kg}$.

\section{Changes in body weight}

Body weight of the MLEMP-treated group began to increase following treatment and maintained a steady increase comparable to the albendazole treated group and the uninfected-untreated group. On the other hand, the infected-untreated group had a lower live weight at the conclusion of the research when compared to their preinfection live weights. (Figure 1).

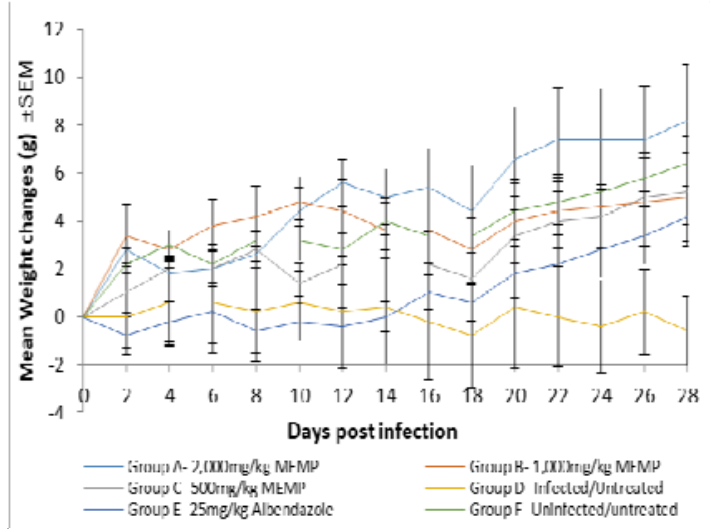

Figure 1: Body weight changes of mice infected with $H$. bakeri larvae and treated with graded doses of MLEMP

\section{Faecal egg count (FEC)}

The mean pre-patent period evidenced by the occurrence of strongyle (H. bakeri) eggs in the faeces of all the infected mice groups was $8 \pm$ 2.0 days (range $6-10$ days). The outcome of treatment of the various groups with MLEMP on faecal egg count is presented in Figure 2.

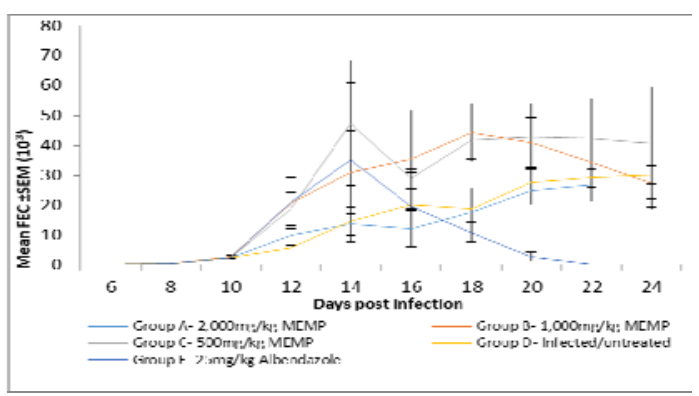

Figure 2: Mean faecal egg count of mice infected with $H$. bakeri larvae and treated with graded doses of MLEMP

\section{Post-mortem worm count}

The mean post mortem worm counts (PMC) \pm SEM of the various groups are shown in Figure 3 . Mice in group A (treated with $2,000 \mathrm{mg} / \mathrm{kg}$ of the extract) had significantly lower $(p<0.05)$ worm burden than mice in any of the other extract treated groups. At the end of the study, adult worms were not present in both the albendazole (group E) treated and the uninfected-untreated ( $F$ group) groups.

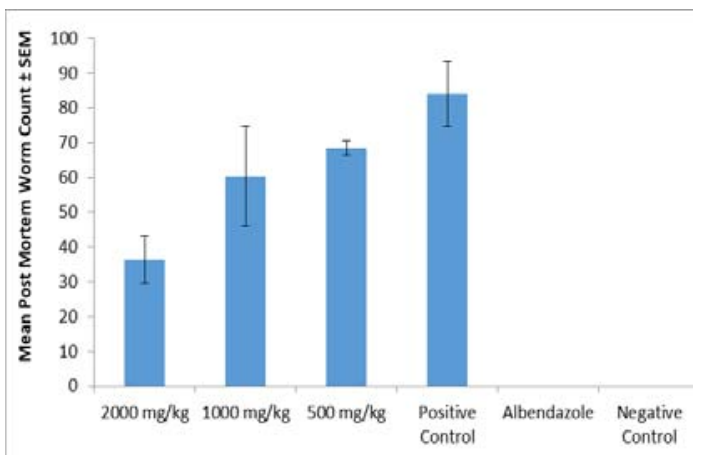

Figure 3: Mean post -ortem worm count of mice infected with $H$. bakeri larvae and treated with graded doses of MLEMP. *Positive control: Group D (infected untreated), Negative control: Group F (uninfected untreated)

\section{Packed cell volume}

The changes in the PCV of the mice in the various groups are shown in Figure 4. The PCV of all the groups were comparable at day $0(p>$ $0.05)$. However, following infection, a sharp drop was recorded in all the infected groups $(A-E)$ from day 4 and this continued up to day 12 post infection when the lowest values were attained in all the groups. PCV of the uninfected-untreated 
group remained within their day 0 values without any significant $(p>0.05)$ changes while the decline in PCV continued unabated in the infected-untreated group till the conclusion of the experiment. Following treatment an increase in PCV towards the normal pre-infection values in the treatment groups was observed.

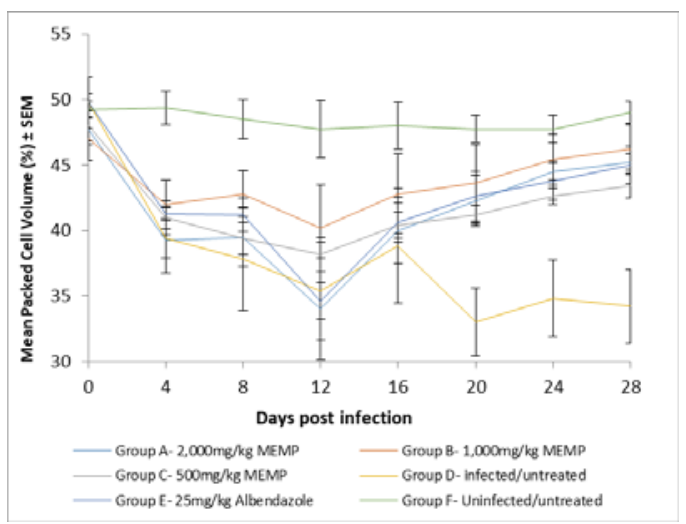

Figure 4: Mean packed cell volume of mice infected with $H$. bakeri and treated with graded doses of MLEMP

\section{Red blood cell count}

Similar to the PCV, the RBCs of all the mice in groups $A-E$ showed a sharp drop from day 4 to attain its lowest values by day 12 post-infection and was significantly lower $(p<0.05)$ than that of the uninfected-untreated group (Figure 5). Following treatment (MLEMP and albendazole), the RBC counts of groups $A-E$ commenced recovery to their pre-infection values, while the $\mathrm{RBC}$ of the infected-untreated group continued to decline till the conclusion of the study and was significantly lower $(p<0.05)$ than all the other groups.

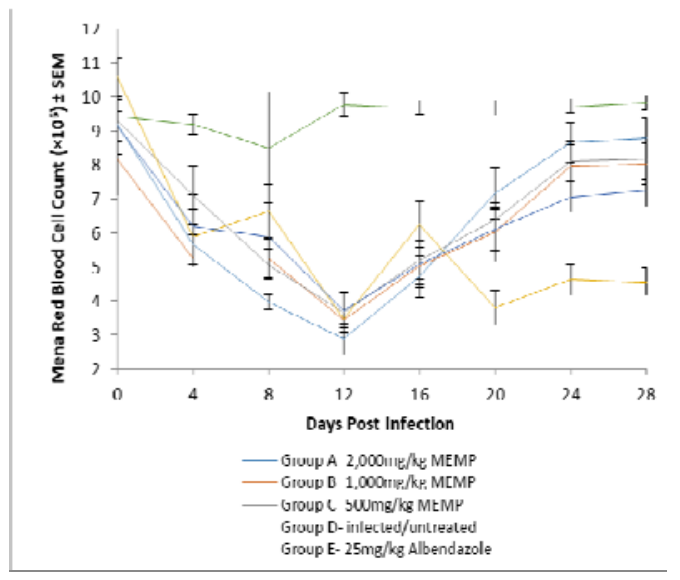

Figure 5: Mean Red Blood Cell Count $\left(\times 10^{6}\right) \pm$ SEM of mice in experimental groups

\section{White blood cell count}

The white blood cell count (WBC) of the experimental animals during the study is represented in figure 6 . An increase in the WBC count was observed in the infected groups following establishment of the infection. This increase became significantly higher than that of the uninfected-untreated group by day 16 post infection and remained relatively higher till the end of the study.

Other haematological parameters such as the haemoglobin concentration, red cell indices ( $\mathrm{MCV}, \mathrm{MCH}, \mathrm{MCHC}$ ) were all indicative of anaemia in the infected groups and showed an improvement back to pre-infection values following treatment with the extract and albendazole in the respective groups.

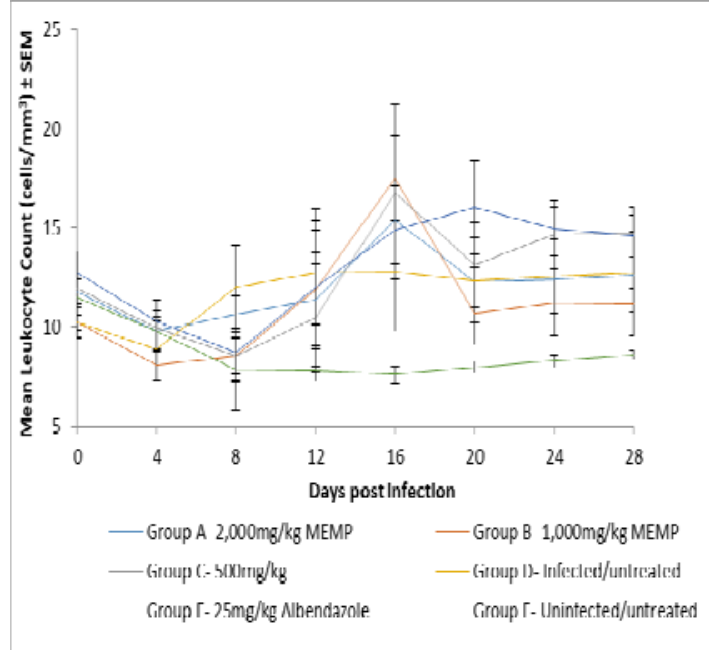

Figure 6: Mean Leukocyte Count (cells/mm3) \pm SEM of mice in experimental groups.

\section{Serum chemistry}

The total protein of Group A was significantly higher $(p<0.05)$ than those of all the groups while Group D had the lowest. Mice in Group D also had significantly lower $(p<0.05)$ serum albumin levels than Group A while the rest of the groups were comparable just as in the Total protein.

The results of the globulin fraction, blood urea nitrogen and alanine transaminase were not significantly different $(p<0.05)$ in all the groups. Although the values for BUN and ALT were lower in the albendazole group, when compared to the other groups they were not significantly $(p>$ 0.05) different (Table 4). 
Table 4: Mean values of serum enzymes of mice infected with $H$. bakeri and treated with MLEMP

\begin{tabular}{lccccc}
\hline Group & $\begin{array}{c}\text { Total protein } \\
(\mathbf{g} / \mathbf{d L})\end{array}$ & $\begin{array}{c}\text { Albumin } \\
(\mathbf{g} / \mathbf{d L})\end{array}$ & $\begin{array}{c}\text { Globulin } \\
(\mathbf{g} / \mathbf{d L})\end{array}$ & $\begin{array}{c}\text { BUN } \\
(\mathbf{m g} / \mathbf{d L})\end{array}$ & $\begin{array}{c}\text { ALT } \\
\text { (units/L) }\end{array}$ \\
\hline $\mathrm{A}$ & $33.06^{\mathrm{a}}( \pm 2.43)$ & $5.88^{\mathrm{a}}( \pm 0.65)$ & $27.18( \pm 2.65)$ & $52.52^{\mathrm{ab}}( \pm 3.48)$ & $26.84( \pm 1.19)$ \\
$\mathrm{B}$ & $30.64^{\mathrm{ab}}( \pm 2.47)$ & $5.75^{\mathrm{ab}}( \pm 0.39)$ & $24.89( \pm 2.65)$ & $59.35^{\mathrm{a}}( \pm 1.50)$ & $28.86( \pm 2.41)$ \\
$\mathrm{C}$ & $30.64^{\mathrm{ab}}( \pm 2.26)$ & $5.52^{\mathrm{ab}}( \pm 0.25)$ & $25.12( \pm 2.42)$ & $56.04^{\mathrm{a}}( \pm 4.94)$ & $25.28( \pm 1.67)$ \\
$\mathrm{D}$ & $26.84^{\mathrm{b}}( \pm 1.17)$ & $4.62^{\mathrm{b}}( \pm 0.05)$ & $22.21( \pm 1.17)$ & $57.14^{\mathrm{a}}( \pm 2.36)$ & $27.42( \pm 5.77)$ \\
$\mathrm{E}$ & $28.17^{\mathrm{ab}}( \pm .99)$ & $4.77^{\mathrm{ab}}( \pm 0.41)$ & $23.40( \pm 0.62)$ & $45.12^{\mathrm{b}}( \pm 3.72)$ & $19.68( \pm 1.58)$ \\
$\mathrm{F}$ & $27.89^{\mathrm{ab}}( \pm .43)$ & $4.7^{\mathrm{ab}}( \pm 0.07)$ & $22.51( \pm 0.58)$ & $59.2^{\mathrm{a}}( \pm 1.07)$ & $27.91( \pm 4.15)$ \\
\hline
\end{tabular}

${ }^{*} \mathrm{a}, \mathrm{b}$, and c are different superscripts in a row denote significant differences at $p \leq 0.05$ probability level. *Group A 2,000mg/kg MLEMP, Group B 1,000mg/kg MLEMP, Group C - 500mg/kg MLEMP, Group D - infected and untreated, Group E - 25mg/kg Albendazole, Group F - uninfected and untreated

\section{DISCUSSION}

Phytochemical analysis of $M$. pudica revealed the presence of flavonoids, alkaloids, tannins, reducing sugars, carbohydrate, and saponin, as have earlier been reported $[8,15]$. Various anthelmintic studies on plant extracts have attributed the anthelmintic effects of such plants to the presence of some phytochemical components like tannins, alkaloids, saponin, polyphenols, carotenoids, coumarine, cardenolides, triterpenes [16]. Tanniferous plants have been reported to possess anthelmintic activities [11]. Alkanoids and saponins contained in plants have also been shown to contribute to the anthelmintic activities of such medicinal plants [17]. Thus, the presence and activities of the phytochemical constituents such as alkaloids, tannins and saponins in MLEMP may have been responsible for the anthelmintic activities recorded both in vitro and in vivo in this study. In the acute toxicity study, the mice did not exhibit any signs of toxicity such as changes in appearance (rough/ruffled hair coat and drooling), behavior (excitement, depression, dyspnea/polypnea), diarrhea or death even at the upper limit dose of $5,000 \mathrm{mg} / \mathrm{kg}$ body weight administered per os. Consequently, the LD 50 of the extract was taken to be above $5,000 \mathrm{mg} / \mathrm{kg}$ bw.

Based on the United States Environmental Protection Agency categorization and the World Health Organization Acute Hazard ranking [18], MLEMP was therefore considered 'not acutely toxic'. The results of the Probit-log analysis of the Egg hatch assay of MLEMP in comparison with the standard anthelmintic, Albendazole gave $\mathrm{LC}_{50}$ values of 1.160 and -1.042 respectively. This indicated a very low in vitro anthelmintic effect of MLEMP. A concentration-dependent inhibition of egg hatch was recorded for both MLEMP and Albendazole during this study.

Albendazole showed a higher anthelmintic activity than MLEMP in this study even though the concentrations of albendazole used were twenty times lower than those of the plant extract. The greater anthelmintic activity of albendazole compared to MLEMP as observed in the study can be attributed to its purity. In the in vivo study using the Heligmosomoides bakeri rodent model, a prepatent period of $8 \pm 2.0$ days (range 6 - 10 days) was recorded. Various researchers have recorded varying prepatent periods; Ngongeh et al [11] recorded a prepatent period of 10 days, Yondo et al [19] recorded 9 11 days and $6-8$ days was observed by Udobi et al [14]. A steady increase in the FEC was recorded in all the infected groups $(A-E)$ following infection. The clearance of the H. bakeri parasite in the albendazole treatment group (E) started 2 days post-treatment (pt) and final clearance was recorded 6 days pt. This is similar to the reports of Udoha et al [20] who also recorded total clearance of $H$. bakeri in mice treated with $30 \mathrm{mg} / \mathrm{kg}$ body weight of albendazole 6 days post treatment.

Weight loss is one of the major clinical manifestations of gastro-intestinal parasitism [21]. Following treatment in the groups, live weights improved while fluctuations were recorded in the infected untreated group. Weight gains were recorded by the end of the experiment in the treatment groups and the uninfected untreated group when compared to their baseline pre-infection weights. The increase in live weight is indicative of the extract's ability to reduce the effects of the parasite.

A sharp drop was observed in all the haematological parameters (packed cell volume, red blood cell count and haemoglobin concentration) in the infected groups following infection. $H$. bakeri is a haematophagous nematode and causes blood loss through blood sucking and haemorrhage from the duodenal mucosa. The anaemia observed before the evidence of maturity is most likely as a result of the haemorrhage and subsequent blood loss arising from the burrowing and tunnelling of the third stage larvae into the muscularis of the intestine [22] where they develop and re-emerge 
into the intestinal lumen as juveniles. The results of the red blood cell indices (MCV, $\mathrm{MCH}$ and $\mathrm{MCHC})$ were indicative of macrocytic hypochromic anaemia. The MCV increased following infection while a decrease in the $\mathrm{MCHC}$ was observed; this is typical of the blood loss anaemia that accompanies most worm infections like those due to hookworms. Previous studies have shown that anaemia is a common feature in $H$. bakeri infections $[11,23]$. The haematological values of the treatment groups however improved following treatment probably as a result anthelmintic effects of MLEMP on the worms and possible anti-inflammatory and wound healing activities of the phenols, alkaloids and flavonoids contained in MLEMP $[6,15]$. It is likely that the phenolic compounds (tannin and flavonoids) were able to counter the inflammation that usually accompanies gastrointestinal parasitism.

The increase in the leukocyte count can be attributed to the infection. Parasitic infections have been reported to elicit leucocytosis especially an increase in eosinophils [24].

The results of the alanine transaminase (ALT) and blood urea nitrogen (BUN) suggested that the extract had no adverse effect on the liver and kidneys at the given doses. Levels of ALT and BUN are essential liver and kidney markers; high level of these enzymes in sera are indicative of ongoing liver or kidney damage respectively. Hypoproteinaemia and hypoalbuminaemia were recorded in the infected untreated group (D). The loss in the serum proteins observed in this study in the infected untreated group was attributed to the blood loss and malabsorption associated with hookworm infections [25]. The extract was however able to improve the total protein and albumin levels $(p<0.05)$ when compared to the control groups $\mathrm{D}$ and $\mathrm{E}$.

\section{CONCLUSION}

The findings from the study indicate a low anthelmintic efficacy of MLEMP. However, this level of anthelmintic effect reduced the faecal egg count and worm burden, and improved the haematological values and serum proteins of the treated mice.

\section{DECLARATIONS}

\section{Acknowledgement}

The authors wish to appreciate Dr LA Ngongeh (Department of Veterinary Microbiology and Parasitology, Michael Okpara University of Agriculture, Umudike) for supplying the experimental parasites used for the study.

\section{Funding}

This research was partly funded with an Academic Scholarship award from Anambra State Government of Nigeria.

\section{Conflict of interest}

No conflict of interest is associated with this study.

\section{Contribution of authors}

We declare that this work was done by the authors named in this article and all liabilities pertaining to claims relating to the content of this article will be borne by the authors. Nzeakor, T.A., Nwosu, C.O and Eke, I.G designed the experiment. Nzeakor, T.A., Udobi, M.I., Eke, I.G., Ezeh, I.O., Eze, U.U and Dan-Jumbo, S.O carried out the laboratory research. Nzeakor, T.A and Idika, I.K., analyzed the data. Nzeakor, T.A, and Nwosu, C.O prepared the manuscript. All authors revised the manuscript and approved the final version.

\section{Open Access}

This is an Open Access article that uses a funding model which does not charge readers or their institutions for access and distributed under the terms of the Creative Commons Attribution License (http://creativecommons.org/licenses/by/ 4.0) and the Budapest Open Access Initiative (http://www.budapestopenaccessinitiative.org/rea d), which permit unrestricted use, distribution, and reproduction in any medium, provided the original work is properly credited.

\section{REFERENCES}

1. Sargison ND. Pharmaceutical control of endoparasite infections in sheep. Vet Clin North Am Food Anim Pract 2011; 27, 139-156.

2. Van den Brom $R$, Moll $L$, Kappert C, Vellema $P$. Haemonchus contortus resistance to monepantel in sheep. Vet. Parasitol. 2015; 209: 278-280.

3. Ruano ZM, Carolina N, Mateus TL. Gastrointestinal parasites as a threat to grazing sheep. Large Animl Rev 2017; 23 (6): 231 - 238.

4. Kokane DD, More RY, Kale MB, Nehete MN, Mehendale $P C$, Gadgoli $\mathrm{CH}$. Evaluation of wound healing activity of root of Mimosa pudica. J Ethnopharmacol. 2009; 124:311-5.

5. Joseph B, George J, Mohan J. Pharmacology and Traditional Uses of Mimosa pudica. Int $\mathrm{J}$ Pharm Sci Drug Res. 2013 (5): 41-44.

Trop J Pharm Res, December 2020; 19(12): 2629 
6. Azmi L, Singh MK, Akhtar AK. Pharmacological and biological overview on Mimosa pudica Linn. Int. J. of Pharm. \& Life Sci. (IJPLS), Vol. 2, Issue 11: Nov.: 2011, 1226-1234

7. Robinson RD, Williams LA, Lindo JF, Terry SI, Mansingh A. Inactivation of Strongyloides stercoralis filariform larvae in vitro by six Jamaican plant extracts and three commercial anthelmintic. W Indian Med JI 1990; 39 (4): $213-217$.

8. Chandran RP, Deepak V, Krishna S, Fathima S, Thaha A, Raj J. Analysis of phytochemical constituents and anthelmintic activity of leaf extracts of Mimosa pudica $L$. Asian J. Biomed Pharm Sci 2018 vol. 8; (65) pp. 268 274.

9. Mahdi S, Altikriti Y. Extraction of natural products. Biologiskt Aktiva Naturprodukter i Läkemedelsproduktion HT, 2010; vol. 20, pp. 3-5.

10. Trease, Evans. Pharmacognosy. Springer publication, 2007; p. 153-7.

11. Ngongeh LA, Fakae BB. Effect of Quebracho tannin drenching on Heligmosomoides bakeri infection in mice. Int. J. Sci. Nat. 2011; 2, 132 - 135.

12. Lorke $D$. A new approach to acute toxicity testing. Arch. Toxicol. 1983:53, 275 - 287.

13. Idika IK, Eze UU, Aneke CI, Ezeudu TA, Iheagwam CN, Ezeh IO, Umeakuana PU, Nwosu CO. Responses of the Nigerian local breed of dogs to single pulse, trickle and trickle non-escalated patterns of Ancylostoma caninum infections. Res. J. Parasitol. 2016; 1 (1 - 2), 521 - 527.

14. Udobi MI, Nzeakor TA, Eke IG, Ezeh IO, Onyeabor A, Idika IK, Nwosu CO. Evaluation of the anthelmintic potential of Duranta erecta L. (Verbenaceae) fruits used in Nigerian ethnomedicine as a vermifuge. J. Ethnopharmacol. 2018 (216); 57 - 62.

15. Ahmad H, Sehgal S, Mishra A, Gupta R. Mimosa pudica L: An overview. Pharmacogn Rev. 2012; 6(12): 115-124.

16. Kumar T, Gupta A, Gidwani B, Kaur CD. Phytochemical Screening and Evaluation of Anthelmintic Activity of Euphorbia tithymaloidus. Int. J. Biol. Chem. 2015. 9: 295-301.

17. Ali N, Shah SW, Shah I, Ahmed G, Ghias M, Khan I. Cytotoxic and anthelmintic potential of crude saponins isolated from Achillea Wilhelmsii C. Koch and Teucrium Stocksianum boiss. BMC complement altern med, 2011; 11, 106. United States Environmental Protection Agency. Health Effects Test Guidelines OPPTS 870.1100 Acute Oral Toxicity. Prevention, Pesticides and Toxic Substances (7101). EPA 712-C-02-190 December 2002.

18. Yondo J, Komtangi M, Wabo J.P, Bilong CF, Kuiate J, Mpoame M. Nematicidal efficacy of methanol/methylene chloride extract of Rauwolfia vomitoria (Apocynacae) on Heligmosomoides bakeri (Nematoda, Heligmosomatidae) parasite of the white mouse (Mus musculus) J. Med. Plant Res. 2013; 7(34), pp. 32213226.

19. Udoha MU, Okolie NJ, Ijioma SN. Anthelmintic activity of Ocimum gratissimum leaf extract in Heligmosomoides bakeri infected experimental mice. Ann. Biol. Sci. 2015; 3 (4): 1-7

20. Yang Z, Grinchuk V, Smith A, Qin B, Bohl JA, Sun R, Notari L, Zhang Z, Sesaki H, Urban J F, Shea-Donohue $T$, Zhao A. Parasitic nematode-induced modulation of body weight and associated metabolic dysfunction in mouse models of obesity. Infect. Immun., 2013; 81(6), 1905-14.

21. Maizels RM, Hewitson JP, Murray J, Harcus YM, Dayer $B$, Filbey KJ, Grainger JR, McSorley HJ, Reynolds LA, Smith $K A$ ). Immune modulation and modulators in Heligmosomoides polygyrus infection. Exp Parasitol. 2012; 132(1):76-89.

22. Onyeabor Al, Wosu MI, Ohaeri CC. Corprological and haematological parameters of albino mice (Mus musculus) concurrently infected with Heligmosomoides bakeri and Trypanosoma brucei. Open Veterinary Journal, 2013; Vol. 3(2): 96-100

23. Huang L, Appleton JA. Eosinophils in Helominth infection: Defenders and Dupes. Trends Parasitol, 2016: 32 (10) $798-807$.

24. Idika K, Eze U, Aneke C, Nzeakor T, Iheagwam C, Ezeh I, Umeakuana P, Nwosu C. Responses of the Nigerian Local Breed of Dogs to Single Pulse, Trickle and Trickle Non-escalated Patterns of Ancylostoma caninum Infections. Res J Parasitol, 2016: 11(3) 48-54. 